\title{
University-Industry Technological Cooperation For Energy Efficiency: A Case Study
}

\author{
Andréa Paula Segatto-Mendes* \\ E-mail address: apsm@ufpr.br \\ Centro de Pesquisa e Pós-Graduação em Administração - Universidade Federal do Paraná \\ Curitiba, PR, Brazil \\ Nathan Mendes \\ Departamento de Engenharia Mecânica - Pontíficia Universidade Católica do Paraná \\ Curitiba, PR, Brazil
}

\begin{abstract}
The central aim of this article is to demonstrate the development and characteristics of an inter-institutional relationship with a view to perfecting existing technology in reducing the consumption of energy in household refrigerators and also to show the adequacy of the case studied for the most recent preconceived ideas concerning the development of Etzkowitz's Triple Helix. The study refers to the technological cooperation between universities and industries and the presentation of a successful experience in which the joint action of individual institutions led to technological gains for both parties. The data was collected from individual in depth interviews with the research coordinators at the both company and the university. The results obtained showed not only the efficiency of the joint research but also the success of the cooperation and the identification of the practice of new positions raised in recent studies. Thus, by studying the experience of these institutions in technological cooperation, we can see that the productivity and efficiency of the cooperation between the university and the company open up possibilities for contributing to the technological development of the country.
\end{abstract}

Key words: technological innovation; cooperation between university and company; energy efficiency.

Received 20 September 2005; received in revised form 14 December 2005.

Copyright (C) 2006 Brazilian Administration Review. All rights reserved, including rights for translation. Parts of this work may be quoted without prior knowledge on the condition that the source is identified.

\footnotetext{
* Corresponding author: Andréa Paula Segatto-Mendes

Universidade Federal do Paraná, Departamento de Administração, Av. Pref. Lothário Meissner, 632, Jardim Botânico, 80210-170, Curitiba, PR, Brazil.
} 


\section{INTRODUCTION}

The relevance of the process of technological innovation in a company has been reflected on the economic performance of the countries in which they are located since this performance is largely supported by the development and utilization of information and communication technologies (OECD, 2000). Along with this factor, authors like Gaynor (2002), Rogers (2003), Johnston Jr. and Bate (2003) defend the strategic importance of the innovation process for the companies themselves. The relationship between the competitive capacity of companies and countries with the knowledge and its management have made the importance of structures like scientific and technological research through partnerships between universities and companies increasingly evident. These partnerships contribute to the development of science, its applications and the appropriation of innovations resulting thereof, and progress from the paradigm of industrial society to the society of knowledge (Fujino, Stal, \& Plonski, 1999) can be seen as a crucial factor in the economic, social and cultural growth of nations and organizations.

Furthermore, as stated by Gomes and Kruglianskas (2005), current competitiveness sees innovation management as one of the most relevant administrative practices for business success. To this discourse we may add the perception of Vedovello $(1997,1998)$ which mentions the existence of efforts and initiatives for cooperation between organizations for Research \& Development (R\&D) in recent years, despite the absence of policies to stimulate technological development in the country in recent decades (Lastres, 1997; Alem, Barros, \& Giambiagi, 2002).

This concern has brought universities and companies together, while in almost all countries this closer relationship between these institutions is already a reality and has grown and intensified over the past twenty years. One of the main reasons for this is the ongoing technological revolution, which makes processes and products become obsolete more quickly. In this way, new technologies bring about new industrial sectors that are strongly marked by the incorporation of scientific and technical knowledge (Stal, 1997). Furthermore, when it comes to multinational companies and their subsidiaries, Boehe and Zawislak (2005) comment that these companies can prevent their subsidiaries from establishing interaction with local organizations for carrying out research because they fear that their knowledge and strategic technologies could be leaked to their competitors, although the authors also affirm that: "When there are highly qualified local partners, however, technological cooperation may help the subsidiary acquire specific knowledge from their external partners. This specific knowledge, acquired locally, may be levered on a global scale through other subsidiaries” (p. 2).

In addition, the relationships between universities and industries, besides facilitating the best diffusion and transference of new knowledge, can lead to the creation of jobs and increased income when successful, which means enormous gains for these institutions (Chaimovich, 1999). Therefore, this inter-institutional arrangement for joint research emerges as an important model for development, for both universities and companies, and also the country. However, Brazil does not yet make much use of this type of arrangement, which has led authors to mention this low level of interaction as one of the main factors to explain the low number of innovations developed in the country (Levy, 2005; Pereira \& Kuglianskas, 2005; Stal \& Fujino, 2005).

This paper refers to cooperation between universities and companies and the presentation and description of a successful experiment in which the joint action of different institutions led to greater technological gains for both parties. The central aim is to show the development and characteristics of an inter-institutional relationship with the common goal of perfecting existing technology in systems for reduced consumption of energy in domestic systems of refrigeration and also the adaptation of the case to the most recent preconceived ideas of the development of Etzkowitz's Triple Helix.

In this sense, other goals arise, such as the demonstration of accelerated growth of a fledgling laboratory in a private institution (Pontifical Catholic University of Parana - PUCPR) which sought different mechanisms for its expansion, believing in cooperation between universities and companies 
as one of the propellants for development, new methods of cooperation between industries and university mentioned by Etzkowitz and Leydesdorf (2000) and also the presentation of the results obtained by the laboratory and Electrolux of Brazil for their individual needs.

\section{COOPERATION BETWEEN UNIVERSITY AND COMPANIES}

According to Etzkowitz (2003, p. 299), the term "innovation has taken on a wider meaning. More than the development of new products in companies, it is also the creation of new arrangements between institutional spheres that provide the conditions necessary for innovation". In this sense, cooperation between university and company is also an important instrument in the generation of science and technology in a country since by splitting costs and sharing risks between the two institutions, cooperative research allows for greater investment in the development of new technologies for products and processes that guarantee greater competitiveness to organizations and the broadening of the scientific knowledge of the nation (Segatto-Mendes, 2001).

The connection between universities and companies do not take place overnight. It is an ongoing process in which certain stages must occur. According to Sbragia (1994), these stages are three in number. The first would be the arousal of the will to cooperate and both parties show willingness, with meetings taking place between the participants in order to search for ways to cooperate. The second stage would be the moment in which exchange of information takes place. The attitude is positive and both parties look to exchange information, but few results are obtained. In this stage, at times, universities put together manuals that supply their possibilities and professionals or catalogues with the technologies and services that are at the disposal of the companies. The third stage is the one where cooperation becomes effective. In this case, the search for information of the participating sectors is constant and there is already awareness of the concrete benefits that will stem from this integration.

Inter-organizational relationships such as cooperation between industry and university can be structured in a variety of ways. According to Hall (2004) these relationships can have various degrees of formalization and standardization, frequency of transactions, perceived relevance by each party and a different degree of symmetry of information and transactions. A controversial question in the discussion concerning cooperation between universities and industries revolves around what role would be most suitable for federal, state and local governments in the process. On this subject Plonski (1995) quotes the paper "Science and Technology in the Future Development of Latin America" presented by Jorge Sábato and Natalio Botana at the World Order Models Conference held in Ballagio, Italy in September, 1968, in which the authors discuss the development of Latin America and the role of science and technology in this development, including the cooperation of business and university. To them, it would be important to have the multiple and coordinated action of three elements: government, the productive structure and scientific-technological infrastructure, all fundamental to achieving greater development through this system. They graphically describe this relationship in the form of a triangle (which came to be known as Sabato's Triangle) in which the upper vertex is occupied by the government and the base vertices are occupied by the other two elements.

New figures have been developed from this geometric model, where the representation is done by elaborate networks that are increasingly complex. For example, the model in the form of a tetrahedron, developed by Professor Jorge Domingo Petrilho (Rector of the National University of Mar del Plata in Argentina), which includes a fourth vertex, the financial sector. Another example is the Triple Helix Model cited by Etzkowitz and Leydesdorff (1997a), in which four dimensions are defined: internal transformation in each helix, influence in the other helix, the creation of new coverage of networks and trilateral organizations and the recursive effect of these changes on the institutional spheres. Thus, the growing collaboration between the public, private and academic spheres, in this model, generates the spiral of links at the various stages of the innovation process. As stated by Flores and SegattoMendes (2005, p. 5): "Within this socio-economic reality, the interaction between university, company 
and government must be idealized and planned carefully. In this construct the political will of the central administration of the university and research institutes is included, along with the vocation and conviction of the teaching staff and researchers and a management structure for business, so that it might function as a vehicle institutional connection among academia, the market and government; and the political conscience of the government, especially the local government.”

On of the differentials of the recent studies of Etzkowitz is the perception of a greater approximation between universities and industries, attenuating the reflexes of "different nature" commented on by Plonski (1994). In this sense, Etzkowitz (2003, p. 302) states that "the basis of knowledge and its role in innovation can be explained in terms of changes in the relationships between university, industry and government (see Figure 1)”. This figure shows a better understanding of the development of the so-called "triple helix".

\section{Figure 1: From the Statesman and Laissez-faire the Triple Helix}
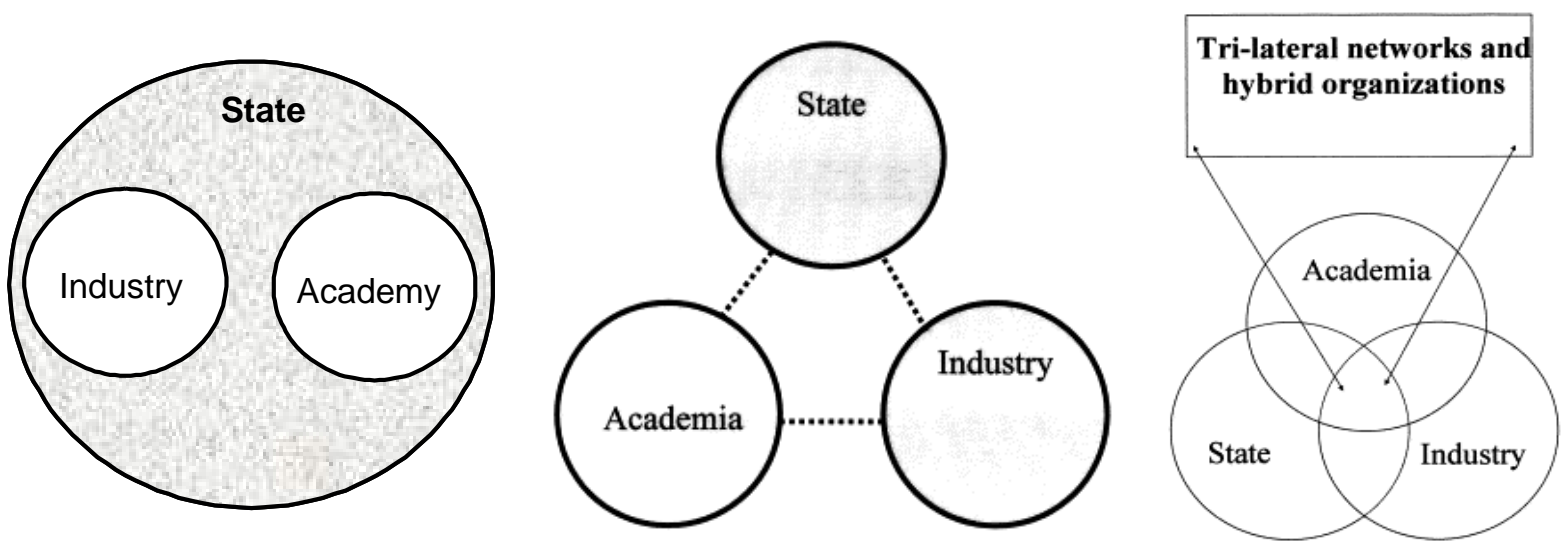

Source: Adapted of Etzkowitz \& Leydesdorff (2000, p. 4).

According to Noveli (2006), the first systematization of Figure 1 shows the government surrounding the universities and industries, directing the relationships of cooperation to be established. The second, (Sabato's Triangle) establishes the clear institutional separation of spheres, albeit with the "government in the upper vertex of the triangle maintaining the role of incentive provider in the relationship, which allows it to act as a director of development" (p. 22). Finally, the third scheme according to Etzkowitz and Leydesdorff (2000, p. 111) "is generating a knowledge infrastructure in terms of superimposition of institutional spheres, with each one performing the role of the other and with hybrid organizations emerging from these interfaces”. Two factors mainly characterize the development of the model of cooperation to the Triple Helix: the capitalization of knowledge and striving for regional development by the university as a third mission.

The capitalization of knowledge concerns the transformation of knowledge into "social capital by academics, involving sectors of the university such as the departments of basic science, from this point on, relatively uninvolved with industry" (Etzkowitz, 1998, p. 825). And on the other hand, Etzkowitz (1998, p. 825) highlights the "emergence of the university as a leading participant in the economic development of its region”.

It must be highlighted that the capitalization of knowledge may be the fruit of the action of entrepreneurial researchers who, in this sense, may develop their own companies or even relate directly to industry, without the need of an intermediary (Etzkowitz, 1998). Furthermore, the perception of the university as an economic development agent in the region is made clear within the context in which knowledge has become an increasingly important "asset", especially considering that universities are recognized as a source for the generation of new knowledge. According to Etzkowitz 
and Leydesdorff (1997b, p. 1): "channeling flows of knowledge into new sources of technological innovation has become an academic task, changing the structure and role of the university".

Considering the Brazilian context, Etzkowitz, Mello and Almeida (2005) when analyzing empirical evidence that they uncovered to support the triple helix model in Brazil, ague that: "Brazil has undergone a transition from a system of top down innovation to a triple helix model, with the university performing an expanded role" (p. 413). In other words, the absorption of new factors, just like the rest of Latin America could be identified in Brazilian cooperative processes because, according to Sutz (1997, p. 12) in an article about the relationships among university, industry and government in Latin America: "Today, universities are increasingly considered, by both governments and companies, as institutions that are more devoted to the 'national good' of economic competitiveness than the 'universal good' of knowledge. As this viewpoint is becoming socially accepted, the limits between academia and industry have been removed”, which would reduce the difficulties in the different natures of partner institutions.

According to Stal (1997, p. 52), developed countries are altering their concepts of the traditional functions of the university, now considering factors such as contracts for research with companies and the financial resources that result from these agreements as indicators of academic performance. As for Brazil, the author states that "the bodies responsible for Brazilian S\&T policies are aware of this tendency around the world and are making available to companies instruments that might lead to an increase in private R\&D investments, be it internally or through partnerships with universities and research institutes.

\section{Cooperation between University and Industry in the Brazilian Context}

A study developed by Segatto (1996) researching the process of university-company cooperation in the Brazilian academic setting, identified the main variables considered relevant to the processes of cooperation in Brazil. The study identified the main motivators, barriers, facilitators, elements of the cooperation process and the resulting satisfaction pointed out by interviewees from the academic and business community, thus delineating the profile of the technological cooperation industry business and university in Brazil.

The study accomplished by the author demonstrated the main motivations for universities that were noted by the interviewees. They were: additional financial resources, additional material resources, the fulfillment of the social role of the university, the prestige that would fall to the researcher, spreading the university's good reputation, obtaining practical knowledge of existing problems and the incorporation of new information to the teaching and research processes of the university. However, the factors: fulfilling the social functions of the university; obtaining practical knowledge of existing problems and the incorporation of new information into the university's teaching and research processes were the most commented on to by the interviewees.

For the companies, the motivation was: access to the highly qualified human resources of the university, the reduction of costs and/or risks involved in R\&D projects, access to more recent knowledge in the academic community, the identification of students from the university for future recruitment and the solution of technical problems that led to the need for cooperative research. The strongest motivation was the access to highly qualified human resources and the solution of technical problems that led to the need for research.

The main barriers mentioned by the study were university bureaucracy, the lengthy time required for the project and differences in the level of knowledge between the people at the university and the people at the company who were involved in the cooperation. As for facilitators, government support funds for research were most mentioned. The study provided insight into how both the universities and companies have agents and/or organizations that participate in the cooperation process, acting as an intermediary for the relationship between partners. At the universities, all the institutions selected have 
at least one organization for this specific purpose and, at the companies, the majority mentioned the existence of such an agent.

The main instruments utilized to cement cooperation were: informal personal relationships, formal personal relationships and formal agreements with a defined aim. But none of the instruments affected over $50 \%$ of the projects, either at universities or companies, there being no single dominant instrument in the processes of cooperative research. Nevertheless, later studies showed that informal contacts are one of the most significant forms of relationship between university and industry on a worldwide scale (Sutz, 2000). Furthermore, other studies developed by Vedovello (1997, 1998) classified the connections that take place in the relationships established between universities and companies as formal, informal and human resources for both technological development and other ends, and that includes a wide range of relationships that may occur among these actors, which can or must be termed as technological cooperation between universities and businesses (Raposo \& Serrasqueiro, 2005).

\section{The Transference of Knowledge}

Cooperation between industry and university does not represent only improved technology of products or the creation of innovations. It also means an exchange of relationship in which the transference of knowledge between parties is very important, as it is through this transference that both parties might achieve better results in the research process. For this reason, transference of knowledge must be structured and encouraged from the beginning of the program so that frequent and open communication should take place between the two groups. Success in the transmission of knowledge is fundamental for adequate growth of the knowledge base of both participants.

Therefore, the choice of the most appropriate instrument for the type of relationship that is established between institutions is very relevant and must contemplate the type of relationship that they desire and which they consider most suitable to achieve their aims. Several descriptions of the possible types of relationships established between the university and the company for joint research into technology can be found in literature. There is no consensus or strict standard for the types of relationships that must be made as they are relationships that involve different groups of people from different backgrounds and researching new subjects. New styles of work should arise naturally according to the demands of the process, which may require more complex structuring of these relationships.

Besides the definition of the type of relationship to be developed, the universities may also develop a specific structure to aid them in the cooperation process. Plonski (1999) conceives of these structures as interface structures, which would be institutional mechanisms developed to promote and facilitate cooperation. The author mentions the following example of interface structure: transference offices, associated foundations, business structures with a mission to interact with the academic sector, nonprofit research institutes, technological institutions, third parties and other institutions. These structural bodies would be the responsible for administering some aspect of the cooperation process such as the collection, administration and distribution of resources, making public that lines of research of the university, contact with potential business partners, the facilitation and maintenance of communication between parties (Segatto-Mendes \& Sbragia, 2002).

\section{METHODOLOGY}

Research can usually be classified into three groups: exploratory, descriptive and causal. According to Selltiz, Wrigutsmann and Cook (1974): "formulating or exploratory studies aim to familiarize with the phenomenon or achieve a new understanding of it, frequently to be able to create a more precise research problem or create new hypotheses, the main focus being the discovery of ideals and 
intuitions". In this study, exploratory research was done, as information was sought through qualitative investigation of the problem in question, hoping to discover ideas and intuitions on the topic.

The method adopted to uncover data was the case study, which is recommended for studies on which one works with a specific case that is considered typical or ideal to explain a certain situation, being useful when it is in its early stages of investigation or seeking to broaden the knowledge we have of a certain topic.

The case study is a method in which a phenomenon is studies and analyzed in its real context, seeking to assess the decisions that were made, why certain attitudes were taken and what their results were. In this way, the causes and consequences of the phenomenon and its development will be made clear, always at the time and under the circumstances in which they occurred.

As a basic purpose, this study was the search for information on the process of cooperation between universities and companies established between the Thermal Systems Laboratory at PUCPR and Electrolux and its contributions to the growth of the participating institutions, it was necessary to choose a method of presenting ideas and signs of how the process took place and developed at the organizations involved. To this end, we opted for the use of in depth interviews with those in charge of the research. The questions were prepared using a basic guide for the central aspects of the subject.

\section{The COOPERATION BETWEen the THERMAl Systems Laboratory AND EleCtroluX}

\section{The Thermal Systems Laboratory (LST - Laboratório de Sistemas Térmicos)}

PUCPR is a university in Paraná State in the city of Curitiba. It was established on 14 March, 1959 by the Archbishop of Curitiba at the time, Dom Manuel da Silveira D'Elboux. Recognized by the federal government on 17 May, 1960 (Decree number 48.232), it was raised by the Santa Sé to the level of pontifical - a title granted to Catholic Universities that have shown over the years that they have provided a great deal of services to the community and the Church - on 8 November, 1985.

Its growth and development led to the creation of new courses over the years. At the moment, the institution offers fifty graduate and nine post graduate courses. The Mechanical Engineering course was established in 1993, and is therefore a new course, which saw its first graduation in 1998.

In 1999, the PUCPR Technological Park was set up and its goal was to provide education, services and create the first research structure for its courses. This park includes the Mechanical Engineering course along with Civil, Mechatronic, Production, Computer, Sanitary, Chemical, Food, Computing and Electric Engineering courses, besides post graduate programs in Mechanical Engineering, Applied Computing Technology and Production and Systems. It has seventy-eight laboratories and a total area of $16,835.87 \mathrm{~m}^{2}$.

The Department of Mechanical Engineering at the University has shown a tendency towards research since the very beginning. The first Master and $\mathrm{PhD}$ program in Mechanical Engineering in Paraná State was offered by the department which, currently has seventeen teaching and research laboratories, covering an area of $1500 \mathrm{~m}^{2}$.

Therefore, in 1997, with the acquisition of a climatic chamber to support laboratory classes for Thermal Systems in the graduate course in Mechanical Engineering, the staff in charge of the subject began setting up a new laboratory, the LST (Thermal Systems Laboratory - www.pucpr.br/lst). In 1998, with the arrival of new staff to the Mechanical Engineering Department, which formed a team with the person in charge of the LST, a discussion was begun on the possibility of carrying out research for the expansion of the structure and laboratory activities. This team was further strengthened by the arrival of a new professor in late 1998. 
As the development atmosphere of products is subject to the rate imposed by the growing demands of the consumer market and the competition, it was seen that there was a need to streamline the cycle of projects by employing advanced tools to test prototypes. The products situated in the vast category of thermal systems, in particular, raised concern over efficiency, which has grown recently owing to the well founded fears of the increasing demand for electrical energy and the low growth in its supply.

Within this context, an integrated system for testing and evaluating the performance of thermal systems was built at the LST. The main part of this integrated system is a chamber capable of simulating various atmospheres in its interior, with controlled temperature and relative humidity. It consists of a $2.5 \mathrm{~m} \times 3.5 \mathrm{~m}$ x 3.0m compartment whose air supply in desired conditions is achieved by a system of air conditioning composed of two external condensing units with total capacity of 29000 $\mathrm{BTU} / \mathrm{h}$, which operates at a range of $-10^{\circ} \mathrm{C}$ to $60^{\circ} \mathrm{C}$. The air is fed through the ducts to the dampers, which have inclination regulation according to the necessary flow and are controlled by Programmable Logic Control (PLC). These insufflate the air through the roof and the air is returned through the floor. As a last step, there are two resistances, which heat the insufflated air if necessary.

This acclimatized room cost around US\$130,000, and the professors believed in greater potential for the use of this investment. At the same time, the laboratory required human resources and complements of permanent material. Thus, in 1998, with energy consumption a strategic subject in Brazil, a research project was put together: "A Study of the Reduction in the Consumption of Energy in Domestic Refrigeration Systems", which was submitted to the RHAE (Human Resources in Strategic Areas) program at the CNPq with approval beginning late in 1998 with the funding made available in January, 1999.

The project was initially programmed for a period of two years. Its main goal was to perform studies focused on the reduction of energy consumption in domestic refrigerated systems. Within this study, two main lines of research should be mentioned. The first was the development and perfection of the experimental apparatus for testing energy consumption according to ISO regulations. The second was the development of computer tools for the acquisition of data from the experimental apparatus and the development of a simulation program for thermal and energy performance analysis of new or existing products.

The approval of the project supplied the laboratory with the qualified human resources it needed to begin its activities through three ITD (Industrial Technological Development) grants for engineers and four for students on engineering courses (ITI - Industrial Technological Initiation). The ITD grants from the $\mathrm{CNPq}$ strengthened the team and the institution by temporarily bringing together professionals who were necessary with for the project but who were not on the payroll. On the other hand, the ITI grants stimulated interest in research and development of this technology in the second and third year of technical schools as well as middle level technicians who had graduated up to three years previously by having them participate in the institution project. During this time, owing to the interest of Electrolux of Brazil in studies into reduced energy consumption for its products, an exchange of information began between the company and the laboratory which would culminate in the cooperative research project that will be discussed.

Currently, the LST takes up an area of $125 \mathrm{~m}^{2}$, divided into two units (LST 1 and LST 2) and its infrastructure in terms of equipment has a total value of around US\$330,000. The LST can be represented by the research group registered at the CNPq which has the same name as the laboratory and which, over the last two years, has published 39 articles at national and international congresses, two in national periodicals and six in specialized international periodicals. The case described in this article, the fruits of the collaboration between PUCPR, the CNPq/RHAE and Electrolux of Brazil led to the development of research that resulted in considerable reductions in energy consumption in domestic refrigerators through the technological perfecting of products, which was relevant not only for the competitiveness of one of the partners but also led to results for the university and the national economy through research into the conservation of energy in the domestic sector. 


\section{The Joint Research}

In 1998, the first conversations between the LST and Electrolux of Brazil took place, with the company's interest in reducing energy consumption in its products the motivation for the first contacts made by the team to provide the research potentials at the LST/PUCPR. These were followed by the first meetings to discuss a possible partnership between the institutions.

Late, there was a period for the exchange of information that led to the definition of priority terms for joint research. In this way a project was begun, which involved the reformulation of these proposals many times to establish the lines of research of the study. Besides the factors related directly to the research, this phase also involved repeated discussions over the clauses of the contract concerning intellectual property of the results obtained, the type of information to be supplied by both parties, control over activities and others. This phase took place approximately from May, 1998 to December, 1999.

PUCPR and Electrolux of Brazil drew up formal agreements and contracts for the development of projects with no pre-defined goals (PUCPR Tecnópolis Program). In other words, there was already a larger contract between the two companies that worked as an umbrella contract because as proposals for cooperation with specific laboratories of the university grew, additional terms would be annexed to each piece of research, thus becoming part of the umbrella contract. Before signing with the LST, another term of cooperation had already been established between the two institutions. In this way, this stage of negotiations and discussions came to a close and a new joint research project was drawn up with the support of the RHAE of the CNPq (Reference 610.041/98-3) and with the LST/PUCPR. A term was added to the formal contract, which became official in January, 2000.

In the additional term concerning the cooperation between the LST/PUCPR and Electrolux, it fell to the company to supply the equipment (refrigerators, freezer, thermal charge packages and loads of R134a refrigerant etc.) and monthly financial packages. The LST/PUCPR would be responsible for the development of research and the preparation of periodical monthly. Activities would be tracked by frequent meetings at which results were presented and new directions for research discussed. In this way we see the interaction in different forms that would be observed in roles designated to the company such as financing scientific research for the university; and the university, which could be described as supplying a service to the company. These different forms of interaction take place jointly with the most traditional activity which would be joint research, which took place through the joint effort of exchanges of perception, ideas, analyses and results between the research team of the company and the research team of the university. In other words, the activities established for the cooperation involved the three forms of interaction simultaneously.

In these two years of formal cooperation, since it could be said informally that the process began in 1998, significant advances were made in the research. However, during the first months, the lack of familiarity between the parties slowed the process down and it was necessary to get to know each other better to establish trust and also develop a common language and more cooperative attitudes. This characterized the occurrence of a situation of conflict since the difficulty in communicating compromised the progress of activities within the expected time frame. The situation became more serious because of a coordinator from the company who had the main management tool and control of the establishment of deadlines that were established according to what this person considered ideal for the company and who demanded that the university team adhere to time frames, which did not suit the process of research of the laboratory.

However, due to internal factors, this coordinator, who had a degree in engineering was transferred to another sector. His substitute, with a degree in technology and administration, brought with him the fruits of his time managerial qualifications, a greater awareness of the different nature of work done at a company and research at a university, which greatly smoothed the path of the joint research as this man sought to consult and respect the limitations of deadlines set by the academics. 
The solving of these conflicts led to intensified relations, with more meetings and informal dialogues by telephone and e-mail among the coordinators from the company and the people at the university. This procedure strengthened the partnership, leading to greater trust and collaboration among the participants and the development of a common language which greatly facilitated activities throughout the remainder of the joint research. According to the interviewees, this process was instrumental in the project's achieving the success that it did.

Following this period of adaptation, the research took off at an improved rate with the establishment of the SIAS program (Integrated Software for Data Acquisition) and FRIGUS (Thermal Simulation Program for Refrigerators). The FRIGUS program was one of the first results of the joint research. It was developed through a method of finite differences to simulate in an integrated and simultaneous fashion the cabinet and circuit of refrigeration in products, resulting in a thermoenergetic performance analysis. One great advantage of this system is that it can test products quickly and at extremely low cost. For example, the alteration of internal volume, the thickness of the wall or the type of thermal isolation can easily be simulated, but an experimental trial of these items would cost a great deal for the company while the use of the program allows for simulations with the same result at a very low cost. Another great advantage of the utilization of this system is the possibility of analyzing products outside of laboratory conditions, i.e. under any condition of temperature and humidity.

Another result was the SIAS, developed for trials of the consumption of energy by refrigerators following standard (ISO) procedures, which facilitated and sped up the process of preparing reports. The need for this procedure also prepared the LST for future certification.

This joint research between the university and the company resulted in the development of incremental technological innovations because it inspired changes that led to the improvement of existing products in addition to the transfer of knowledge between the two parties, since it was necessary for the university to become familiar with the features of the product, the productive system, the technology that is used and the market of its partner, which would interfere in the application of its highly specialized knowledge in the generation of innovations. Likewise, the company needed to perfect its competences to understand and dominate the new knowledge generated and thus absorb the new technology adequately. In this aspect, it is necessary to highlight that the main instrument used by the company was the placing of some of its engineers in Master's Degree programs at the partner university. These engineers did their studies under the guidance of the LST research coordinator. In this way, they helped with the development of activities and wrote their dissertations on questions that formed part of the research as a whole. We also see here that there is another form of interaction besides joint research. Within the development of the partnership research itself, a formal personal relationship was formed through the payment of the Master's Degree course to the university for people who worked for the company in order to contribute to the research through the writing of their dissertations.

In this way, not only was the qualification of the human resources greatly improved, but there was also greater ease in communication and fluency in the transfer of technology, a higher number of dissertations written at the university and consequently a higher number of publications in the Master and $\mathrm{PhD}$ program. It is interesting to consider too that, as stated by the PUCPR professor, the inclusion of the company engineers in the Master's Degree program led to greater understanding among the other participants in the research concerning the company and the goals of study and increased the motivation of these participants since the fact that they worked for the company and were also on the Master's Degree course led to greater collaboration. Furthermore, the research helped with the goal of reducing the consumption of energy in the country, which at the time was a matter of great importance owing to the risks of shortages of energy that the country was experiencing and which forced the nation into a rationing program. The cooperation has already resulted in the conclusion of five engineers from the company with Master's Degrees and currently this process of generating and transferring technology with Electrolux sees two engineers on the master's Degree course in Mechanical Engineering at PUCPR, studying matters that meet the needs of the company. 
Considering the more macroeconomic aspects, the interviewees also mentioned the contribution given to the scientific community and the Brazilian job market: the former being an area of knowledge that has few bibliographic references, but now new publications have been made as a result of the joint research; and the latter due to the training of highly skilled labor for the sector of domestic refrigerators that has resulted from the work that was done.

In quantitative terms for the results up to the present, the development of three computer programs deserves to be highlighted (PAS, SIAS and FRIGUS), along with over eighty trials of energy consumption and the development of mathematical models for simulation and new evaporators and new trial methodologies such as the use of heat fluxmeters.

In terms of documentation, three internal technical reports have been written, totaling over 450 pages, five Master's Degree dissertations have been defended in addition to articles that have been prepared and published at scientific events.

The joint analysis of the three general reports that have been presented so far from this partnership, leads to an outline of the results that the research has achieved, just like the vision of the great potential for innovations and improvements concerning the reduction of energy in products that have yet to be explored.

\section{FinAL CONSIDERATIONS}

The analysis of the cooperation process that has been described allows us to identify various aspects raised in the theoretical framework given in this study. Initially we can see that there were three stages as mentioned above. The first stage, which is characterized by the willingness to cooperate and the first contacts took place in early 1998 when Electrolux and the LST/PUCPR had their earliest conversations to discuss a possible partnership.

The second stage took place between May, 1998 and December, 1999, during which period the exchange of data, proposals and ideas was intensified and contractual conditions were established. And finally, the third stage was begun in January, 2000, when both parties signed a term added to the formal contract that made the cooperative research official. The process ended in January, 2002, when the contract was up.

Motivations for cooperation can also be seen in the concern of the company over the development of technologies to reduce consumption of energy and the possibility of having available the expertise of the university for this development, which would reduce costs of research and provide access to highly qualified workers, in addition to the structure of the university. The laboratory was motivated by the need for additional resources, the best utilization of existing equipment and more interaction with the market, which was one of the necessary stages for its growth and maturing process that led to its becoming the dynamic, experienced and well structured laboratory that it is today.

Two barriers were observed in the early stages of the cooperation. One resulted from the positioning of a coordinator that did not realize the different nature of the partnerships and the specifics that this creates in the process, and the second was due to the need for the parties to get to know each other and establish trust and develop a common language. These difficulties slowed the process down a little at the beginning, but they were later overcome. The role of the government as facilitator could also be clearly identified in the case study, as obtaining resources through the approval of the project by the RHAE Program (Human Resourced in Strategic Areas) of the CNPq (National Research Center) boosted the laboratories capacity and preparedness and provided governmental recognition of its efforts and licensing for research, but it was highlighted by those interviewed that in order to facilitate things, a Master's Degree course for company engineers was given at the PUCPR, which improved communication and team work in both an academic and business sense. 
Likewise, the case study allows us to observe the relative considerations for the cooperation of industry and university found in literature. In the study we saw the occurrence of the third mission of the university, i.e. be an agent of regional development which is one of the conceptual modifications that led to what Noveli (2006) called Triple Helix III. The performance of this role is seen in the cooperation in study in the relevance of its research goal in the national given context, for besides proposing improvements to products that impact a strategic sector of the national economy (energy), the research led to more competitiveness in an industry situated in the same city and state as the university, brining economic regional development. What also seems to have contributed to the reduction of difficulties inherent to the institutions, paraphrasing Sutz (1997) the way companies and governments view universities as institutions devoted to the "national good" of economic competitiveness rather than the "universal good" of knowledge, tends to diminish the limits between academia and industry as they become socially accepted. So much so that, despite the questions asked to the interviewees, neither party managed to pinpoint any other moment or conflict during the cooperation, let alone major problems or difficulties.

When it comes to intermediation, the existence of the ICET (Institute of Exact Sciences and Technology) at the university was especially helpful with cutting through the red tape, even for having developed the so-called umbrella contract. And the Additional Term was used as an instrument that worked as a formal agreement with a defined goal, considering the instruments mentioned in the theoretical framework given.

The study demonstrated the use of different forms of interaction between university and business for the consolidation of cooperation such as the financing of scientific research at the university by the company; the providing of services of the university to the company; the formal personal relationship created by providing company workers with a course at the university and the research itself that was carried out jointly.

The transfer of knowledge was done through meetings, reports, computing programs handed to the company and the Master's Degree program. This latter deserves an additional comment as it was an adaptation to the needs and proposals of the joint research as it also ensured better assimilation of technology to be transferred to qualify the workers better for receiving the newly created knowledge, facilitating the common language between the parties and bringing them closer together, strengthening their working relationship.

The results of the cooperation can be seen mainly in the products that were obtained (three computer programs - PAS, SIAS and FRIGUS), the work carried out (over eighty tests of energy consumption), technical reports (three internal technical reports, totaling over 450 pages), five defended dissertations for the Master's Degree and articles published at scientific events. There are also other results to consider, such as the incremental innovation that was done, i.e. the improvement of energy efficiency; the exchange of knowledge and the training of workers.

Furthermore, the advantages that were obtained were clear. The company obtained new technology that allows for simulations to reduce its expenditure on research and lead to a competitive advantage for its products by making them more efficient when it comes to energy consumption, especially at a time when the energy economy has become strategic in maintaining and increasing sales in the market for electrical household goods. The university gained additional resources that it required for its laboratory and the satisfaction of developing a technological instrument that meets the needs of the Brazilian market, considering the current relevance for Brazil of studies into the reduction of energy consumption. Finally, the Master's Degrees of PUCPR obtained by the five engineers from Electrolux sows that there are common advantages to both parties in cooperation processes between universities and companies, as these Master's Degrees stemmed from the cooperative research outlined in this paper.

In this way, we can see through the study the experiment of these institutions in technological and productive cooperation and the efficiency of the cooperation between a privately run university and company. This cooperative relationship between an academic institution and a company has to be 
highlighted, since most of the cases described in national publications refer to cooperation between companies and public universities.

It is also worth mentioning, especially in the current world energy context, that technological advances for the reduction of energy consumption do not only mean precious advantages in competitive terms for the company and how its joint action with the scientific community guarantees its position as a leader. But it also plays a relevant social role, since a study into saving electricity in refrigerators can help reduce the need for high investments in the production or import of energy, reducing the risks of a black out and consequently bringing benefits to society in terms of comfort and quality of life.

\section{REFERENCES}

Alem, A C., Barros, J. R., \& Mendonça, G. F. (2002). Bases para uma política industrial moderna. Anais do Fórum Nacional do Instituto Nacional de Altos Estudos, Rio de Janeiro, RJ, Brasil, 14.

Boehe, D. M., \& Zawislak, P. A. (2005). Os papéis das subsidiarias localizadas no brasil na estratégia de desenvolvimento de produto de empresas multinacionais. Anais do Seminário LatinoIberoamericano de Gestión Tecnológica - ALTEC, Salvador, BA, Brasil, 11.

Chaimovich, H. (1999, outubro/dezembro). Por uma relação mutuamente proveitosa entre universidade de pesquisa e empresas. Revista de Administração da USP, 34(4), 18-22.

Etzkowitz, H. (1998, December). The entrepreneurial university and the emergence of the democratic corporatism. In H. Etzkowitz (Org.). The norms of entrepreneurial science: cognitive effects of the new university-industry linkages. Research Policy, 27(8),823-833.

Etzkowitz, H. (2003, January). Research groups as 'quasi-firms': the invention of the entrepreneurial university. Research Policy, 32(1), 109-121.

Etzkowitz, H., Leydesdorff, L. (1997a, February). Introduction to special issue on science policy: dimensions of the triple helix of University-industry-government relations. Science and Public Policy, 24(1), 2-5.

Etzkowitz, H., Leydesdorff, L. (Orgs). (1997b). Universities and the globlal knowledge economy: a triple helix of university-industry-government relations. New York: Continuum.

Etzkowitz, H., \& Leydesdorff, L. (2000, February). The dynamics of innovation: from national systems and "mode 2" to a triple helix of university-industry-government relations. Research Policy, 29(2), 411-424.

Etzkowitz, H., Mello, J. M. C., \& Almeida, M. (2005, May). Towards “meta-innovation” in Brazil: the evolution of the incubator and the emergence of the triple helix. Research Policy, 34 (4), 109-123.

Flores, M. J., \& Segatto-Mendes, A. P. (2005). Contribuições da cooperação universidade - empresa para a capacitação tecnológica de PME's moveleiras do pólo de Arapongas. Anais do Seminário Latino-Iberoamericano de Gestión Tecnológica - ALTEC, Salvador, BA, Brasil, 11.

Fujino, A., Stal, E., \& Plonski, G. A. (1999, outubro/dezembro). A proteção do conhecimento na universidade. Revista de Administração da USP, 34(4), 46-55.

Gaynor, G. H. (2002). Innovation by design: what it takes to keep your company on the cutting edge. New York: AMACOM. 
Gomes, C. M., \& Kruglianskas, I. (2005). o processo de gestão de fontes externas de inovação em empresas industriais. Anais do Seminário Latino-Iberoamericano de Gestión Tecnológica, Salvador, BA, Brasil, 11.

Hall, R. H. (2004). Organizações - Estruturas, processos e resultados (8a ed., pp. 191-222). São Paulo: Pearson/Prentice Hall.

Johnston, Jr., R., \& Bate, D. J. (2003). The power of strategy innovation: a new way of linking creativity and strategic planning to discover great business opportunities. New York: AMACOM.

Lastres, H. M. M. (1997, outubro). A Globalização e o Papel das Políticas de Desenvolvimento Industrial e Tecnológico. (Texto para Discussão No 519). Convênio Ministério do Planejamento e Orçamento - IPEA/CEPAL. Brasília.

Levy, C. (2005, setembro 2 a 8). Lei da inovação já tramita no congresso. Jornal da Unicamp, (188), pp. 6-7. Pesquisa e Desenvolvimento. Recuperado em 13 agosto, 2005, de http://www.unicamp.br/unicamp/unicamp_hoje/jornalPDF/188-pag06.pdf

Noveli, M. (2006). Cooperações Universidade-empresa em parques tecnológicos: o caso Tecnopuc. Dissertação de Mestrado. Centro de Pesquisa e Pós-Graduação em Administração/CEPPAD, UFPR, Curitiba, PR., Brasil.

Organization for Economic Co-operation and Development - OECD (2000). A new economy? the changing role of innovation and information technology in growth. Paris: Author.

Pereira, J. M., \& Kruglianskas, I. (2005). Políticas de fomento à inovação: as fragilidades da lei de inovação tecnológica do Brasil. Anais do Seminário Latino-Iberoamericano de Gestión Tecnológica, Salvador, BA, Brasil, 11.

Plonski, G. A. (1994). Cooperação empresa-universidade na ibero-américa: estágio atual e perspectivas. Anais do Simpósio de Gestão da Inovação Tecnológica, São Paulo, SP, Brasil, 18.

Plonski, G. A. (1995). Cooperacion empresa-Universidad en Iberoamerica: estágio atual e perspectivas. In G. A. Plonski (Ed.) Cooperacion empresa-universidad en Iberoamerica: avances recentes. São Paulo: CYTED.

Plonski, G. A. (1999, outubro/dezembro). Cooperação universidade-empresa: um desafio gerencial complexo. Revista de Administração da USP, 34(4), 5-12.

Raposo, M. L., Serrasqueiro, Z. (2005, abril/junho). A universidade e o desenvolvimento regional. Cadernos de Economia, (71), pp. 100-104. Recuperado em 24 setembro, 2005, de www.cadernoseconomia.com.pt/ce71/mario_lino_raposo.pdf

Rogers, E. (2003). Diffusion of innovations (5a ed.). New York: Free Press.

Sbragia, R. (1994). A experiência da universidade de São Paulo. Revista Ciencia, entrevista em São José - Costa Rica.

Selltiz, C., Wrigutsmann, L., \& Cook, S. (1974). Métodos de pesquisa nas relações sociais (3ª edição) São Paulo: Herder. 
Segatto, A. P. (1996). Análise do Processo de Cooperação Tecnológica Universidade - Empresa: Um Estudo Exploratório. Dissertação de Mestrado. Faculdade de Economia, Administração e Contabilidade, USP, São Paulo, SP. Brasil.

Segatto-Mendes, A. P. (2001). Teoria de Agência Aplicada à Análise de Relações entre os Participantes dos Processos de Cooperação Tecnológica Universidade-Empresa. Tese de Doutorado. Faculdade de Economia, Administração e Contabilidade, Universidade de São Paulo, SP, Brasil .

Segatto-Mendes, A. P., \& Sbragia, R. (2002, outubro/dezembro). O processo de cooperação universidade-empresa em universidades brasileiras. Revista de Administração da USP, 37(4), 5871.

Sutz, J. (1997). The new role of university in the productive sector. In. H. Etzkowitz, \& L. Leydesdorff (Orgs.). Universities and the global knowledge economy: a triple helix of universityindustry-government relations (pp. 11-20). New York: Continumm.

Sutz, J. (2000, February). The university-industry-government relations in Latin America. Research Policy, 29(2), pp. 279-290.

Stal, E. (1997). Centros de pesquisa cooperativa: um modelo eficaz de interação universidadeempresa. Tese de Doutorado. Faculdade de Economia, Administração e Contabilidade, USP, São Paulo, SP, Brasil.

Stal, E., \& Fujino, A. (2005). Aprimorando as Relações Universidade-Empresa-Governo no Brasil: A Lei de Inovação e a Gestão da Propriedade Intelectual. Anais do Seminário Latino-Iberoamericano de Gestión Tecnológica, Salvador, BA, Brasil, 11.

Vedovello, C. (1997). Science park and university-industry interaction: geographical proximity between the agents as a driving force. Technovation, 17(9), 491-502.

Vedovello, C. (1998, July). Firms' R\&D activity and intensity and the university-enterprise partnerships. Technological Forecasting and Social Change, 58(3), 215-226. 